\title{
Nutritive Traits and the Use of Guar Meal in the Nutrition of Farm Animals
}

\author{
Mihai-Iacob BENȚEA ${ }^{1) *}$, Aurel ŞARA ${ }^{1)}$ \\ 1) Department of Animal Nutrition, University of Agricultural Sciences and Veterinary Medicine, Cluj- \\ Napoca, 3-5 Manastur Street, 400372, Cluj-Napoca, Romania \\ *Corresponding author, e-mail: mihaib78@yahoo.com
}

Bulletin UASVM Animal Science and Biotechnologies 72(2) / 2015

Print ISSN 1843-5262; Electronic ISSN 1843-536X

DOI:10.15835/buasvmcn-asb:11357

\begin{abstract}
Guar (Cyamopsis tetragonoloba) is an annual pulse from the dry tropical regions; said to originate from the wild African species $C$. senegalesis. Although the leaves and pods can also be used, the seeds are the most used part of the plant. It has high protein content, with high digestibility and palatability without any toxicity sign, and can be used in farm animal nutrition as protein products. Guar meal is submitted to heat treatment to inhibit the antinutritive factors and significantly increase the product's digestibility and palatability. The Milan based company, Chemical SRL, produces a number of guar meal types such as GUAR 50PF, Guar 60PF and Guar 70PFR. This product can be used for all farm animals, especially cows, swine, poultry and fish, as it is not genetically modified (GMOFree) and no other chemical substances are used during its fabrication process.
\end{abstract}

Keywords: guar, pulses, farm animals

\section{INTRODUCTION}

Guar (Cyamopsis tetragonoloba) is an annual pulse from the dry tropical regions, known to originate from the wild African species $C$. senegalesis. It was first cultivated centuries ago in India and Pakistan (Mudgil et al., 2014), countries that currently hold $80 \%$ of the world's guar production. The plant thrives in arid and semiarid climates, being used worldwide; lately, the cultivation of guar has known an expansion into new regions.

The main uses of guar. The seeds are the most used part of the plant, being similar to soybean seeds, although the leaves and pods can also be used (Wikipedia, 2015). The whole seed contains high levels of hydrocolloids (22-24\%) used in the food industry as binders or thickening agents (guar gum). Guar meal, obtained by grinding the seeds, undergoes a thermal treatment in order to inhibit anti-nutritive substances, after which it can be used in feeds, as a soybean replacement.

Nutritive traits of the guar meal. Guar meal has high protein content, and is at the same time highly digestible and palatable, without showing any toxicity signs. For this reason, it can be used in farm animal nutrition as a high protein product, containing up to $35-45 \%$ crude protein. To significantly increase the product's digestibility and palatability, and provide a high-nutritive low-cost product, guar meal is submitted to heat treatment to inhibit the anti-nutritive factors.

In Europe, the Milan based company Chemical SRL (2014) makes a number of guar meal products, such as GUAR 50PF (Pro-Fat) and Guar 60PF (Pro-Fat); if the process is followed by a heat treatment $\left(120-130^{\circ} \mathrm{C}\right.$ for 3 minutes), Guar 70PFR is obtained.

The following table presents the nutritive value of guar meal (Guar 60PF and Guar 70PFR):

The use of guar meal in farm animal nutrition. Guar meal is used as a food additive (E412), having both ISO and HACCP certifications. It can be used for all farm animals, especially cows, pigs, poultry and fish. Guar 50PF can be used on lactating cows, calves and heifers in a dose of $1,000 \mathrm{~g} /$ day and for fattening cows at a dose of 
Tab.1. The nutritive value of guar meal (Guar 60PF şi Guar 70PFR) (Chemical SRL Milano)

\begin{tabular}{|c|c|c|c|}
\hline Issue & UM & GUAR 60PF & GUAR 70PFR \\
\hline \multicolumn{4}{|c|}{ Crude chemical content } \\
\hline Water & $\%$ & $8.0 \pm 2$ & $4.0 \pm 2$ \\
\hline Crude protein & $\%$ & $52.0 \pm 4$ & $60.0 \pm 4$ \\
\hline Issue & UM & GUAR 60PF & GUAR 70PFR \\
\hline Crude fat & $\%$ & $6.0 \pm 2$ & $7.0 \pm 2$ \\
\hline Crude cellulose & $\%$ & $6.0 \pm 2$ & $4.0 \pm 2$ \\
\hline ADF & $\%$ & 18.28 & 18.28 \\
\hline NDF & $\%$ & 28.35 & 25.35 \\
\hline Crude ash & $\%$ & $6.0 \pm 2$ & $5.0 \pm 2$ \\
\hline $\mathrm{Ca}$ & $\%$ & 0.70 & 0.70 \\
\hline $\mathrm{P}$ (total) & $\%$ & 0.60 & 0.60 \\
\hline $\mathrm{P}$ (available) & $\%$ & 0.25 & 0.26 \\
\hline \multicolumn{4}{|c|}{ Energetic value } \\
\hline ME Ruminants & $\mathrm{kcal} / \mathrm{kg}$ & 3855 & 3951 \\
\hline ME swine & $\mathrm{kcal} / \mathrm{kg}$ & 4037 & 4248 \\
\hline ME poultry & $\mathrm{kcal} / \mathrm{kg}$ & 2650 & 2950 \\
\hline UFL & UFL/ kg & 1.12 & 1.18 \\
\hline UFV & $\mathrm{UFV} / \mathrm{kg}$ & 1.10 & 1.16 \\
\hline \multicolumn{4}{|c|}{ Aminoacid content } \\
\hline Lysine & $\%$ & 2.30 & 3.05 \\
\hline Methionine & $\%$ & 0.70 & 0.89 \\
\hline Met+Cist & $\%$ & 1.40 & 1.90 \\
\hline Threonin & $\%$ & 1.50 & 2.07 \\
\hline Tryptophan & $\%$ & 0.70 & 0.90 \\
\hline \multicolumn{4}{|c|}{ Anti-nutritive Factors } \\
\hline Trypsin inhibitor & $\mathrm{mg} / \mathrm{g}$ & 3.96 & 3.15 \\
\hline Tannins & $\%$ & 1.71 & 1.35 \\
\hline Saponins & $\%$ & 0.38 & 0.32 \\
\hline Phytic acid & $\%$ & 1.62 & 1.23 \\
\hline \multicolumn{4}{|c|}{ Fatty Acids } \\
\hline Saturated & $\%$ & 25.00 & 25.00 \\
\hline Mono-unsaturated & $\%$ & 28.00 & 28.00 \\
\hline Poly-unsaturated & $\%$ & 47.00 & 47.00 \\
\hline
\end{tabular}

800 g/day; Guar 60PF and Guar 70PFR 2000 g/ day in cows, calves and heifers, and 1,500 g/day for fattening cows, respectively. In swine, Guar 50 PFR, 60 PF and 70 PFR can be administered in fattening swine in doses of $2.5-12.5 \%$ and $10-15 \%$ for sows. Guar meal can be administered to birds in doses of $2-6 \%$. For fish, the doses range from $6-12 \%$ in common carp and $4-10 \%$ in trout. Guar meal is not genetically modified (GMO-Free), and no other chemical substances are used during its fabrication process.

\section{REFERENCES}

1. Mudgil D, Barak S, Khatkar BS. (2014). Guar gum: processing, properties and food

2. Applications - A Review". Journal of Food Science and Technology, 51 (3), 409-418.

3. http://www.chemicalsrl.com, Indicative values of Guar 60 PF and Guar 70 PFR Roasted,

4. Product information sheet. Review, accessed march 2015

5. https://en.wikipedia.org/wiki/Guar, accessed march 2015 